\title{
Progesterone concentration in rabbit uterine flushings before implantation
}

\author{
B. D. Cowan, ${ }^{*}$ C. Manes and D. D. Hagerman \\ Departments of Obstetrics and Gynecology, Biochemistry, and Pediatrics, \\ University of Colorado School of Medicine, Denver, Colorado 80220, U.S.A.
}

\begin{abstract}
Uteroglobin (or blastokinin) is a specific protein produced by rabbit endometrium when stimulated by exogenous or endogenous progesterone (Schwick, 1965; Beier, 1968a, b; Krishnan \& Daniel, 1967; Urzua, Stambaugh, Flickinger \& Mastroianni, 1970; Arthur \& Daniel, 1972; Bullock \& Connell, 1973). The protein is known to bind steroids, particularly progesterone (Urzua et al., 1970; Arthur \& Daniel, 1972; Beato \& Baier, 1975), and its role in early rabbit embryonic development may be that of a carrier protein for progesterone (Arthur, Cowan \& Daniel, 1972; El Banna \& Daniel, 1972a, b; Beato \& Baier, 1975). Progesterone can be detected in 5- and 6-day post coitum rabbit blastocysts, 7-, 8- and 9-day post coitum blastocoelic fluid and in uterine washings from 5-day pseudopregnant rabbits (Beier, 1968b; Seamark \& Lutwak-Mann, 1972). We now report measurements of the concentration of progesterone in non-pregnant and pregnant rabbit uterine flushings and plasma.
\end{abstract}

\section{Methods}

Mature virgin rabbits of the New Zealand breed were killed by cervical dislocation at oestrus and 1-6 days post coitum. The uteri were flushed with $5.0 \mathrm{ml} 0.9 \%(\mathrm{w} / \mathrm{v})$ sodium chloride solution through each horn from the oviducal end. The washings were centrifuged at $12,000 \mathrm{~g}$ at $3^{\circ} \mathrm{C}$ for $10 \mathrm{~min}$, and the supernatant fluid was frozen at $-20^{\circ} \mathrm{C}$ until analysed. An average of 7 embryos/animal was recovered. Blood samples were obtained by cardiac puncture with heparin as anticoagulant. The blood was centrifuged at $6000 \mathrm{~g}$ for $10 \mathrm{~min}$, and the plasma was frozen. There were two animals in each group, and the individual samples were analysed in duplicate. Samples $(0.5 \mathrm{ml})$ of plasma or uterine fluid were extracted with $5 \mathrm{ml}$ petroleum ether. The extracts were dried under a stream of nitrogen at $22^{\circ} \mathrm{C}$. Recoveries in the extraction process were measured by adding tritiated progesterone, $17 \alpha$-hydroxyprogesterone or corticosterone to replicate plasma or uterine fluid samples before extraction. The average recovery ( \pm S.D.) of progesterone was $84 \pm 5 \%$, of $17 \alpha$-hydroxyprogesterone $47 \pm 6 \%$, and of corticosterone $0 \cdot 3 \pm 0 \cdot 1 \%$. The unknown amounts of progesterone in the uterine flushings were purified from petroleum ether extracts by chromatography through a Sephadex LH-20 (Pharmacia) column (Murphy, 1971; Carr, Mikhail \& Flickinger, 1971). Recovery of progesterone from the column was greater than $90 \%$. The specificity of the assay is such that the small amount of $17 \alpha$-hydroxyprogesterone present in plasma and the low affinity of $20 \alpha$-dihydroprogesterone for corticosterone-binding globulin (Johansson, 1969) made chromatography of the plasma samples before analysis unnecessary.

The competitive protein-binding assay (Murphy, Engelberg \& Patlee, 1963; Neill, Johansson, Datta \& Knobil, 1967) was employed for progesterone; dog serum was pretreated with Florisil to achieve a twofold increase of the binding of corticosterone under the assay conditions used.

The total protein of the uterine flushings was determined by the method of Lowry, Rosebrough, Farr \& Randall (1951). Uteroglobin concentrations were determined by the method of Johnson, Cowan \& Daniel (1972). The antibody was tested for specificity by a double immunodiffusion plate composed of $1 \%$ agar in saline. Samples $(50 \mu l)$ of antigen or antibody were placed in each well. The reaction of the antibody against uterine fluid of rabbits at 5 days post coitum is shown in Text-fig.

\footnotetext{
* Present address: Naval Regional Medical Center, Portsmouth, Virginia 23708, U.S.A.
} 
1. The major protein fractions were obtained by Sephadex G-75 (Pharmacia) gel chromatography (Arthur et al., 1972). The antibody was clearly suitable for use in the radial immunodiffusion analysis.

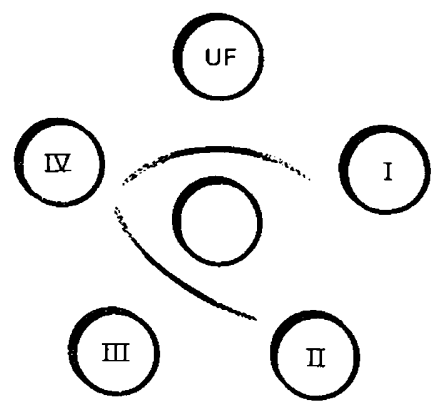

Text-fig. 1. A double immunodiffusion plate showing the presence of a single precipitin band to uterine flushings (UF) from a rabbit at 5 days post coitum and uteroglobin (Fraction III), and the absence of bands to Fractions I, II, and IV. The centre well contained a goat antiserum to uteroglobin and Fractions I, II, III and IV were obtained from chromatography of 5-day post coitum uterine fluid. The plate was photographed after $48 \mathrm{hr}$ and no other bands had developed after 12 days.

The results of the progesterone-binding assay were calculated after log-logit transformation (Ekins \& Newman, 1970). Linear regression analysis of the transformed data was applied to each standard curve, and the correlation coefficient was always greater than 0.989 , demonstrating the precision of the method. Its specificity and accuracy have been described (Neill et al., 1967), and the sensitivity of the assay (defined as the $95 \%$ confidence limit of the lowest $(0 \cdot 2 \mathrm{ng})$ point of the standard curve) was $0 \cdot 1 \mathrm{ng}$.

\section{Results}

Regression analysis of the results (Table 1) showed that there was a statistically significant increase $(P<0.01)$ in the concentration of progesterone in plasma and uterine flushings. The latter was paralleled by an increase in uteroglobin and total protein concentration as expected. The amount of progesterone present in the uterine flushings probably cannot be accounted for by simple serum contamination because of the much higher progesterone: protein ratio in the flushings than in blood. Ultrafiltration of plasma as a source of the hormone cannot be ruled out, but specific secretion seems equally likely.

Table 1. The changes in the concentrations of progesterone, total protein and uteroglobin in the uterine flushings of rabbits at different times after mating

\begin{tabular}{|c|c|c|c|c|}
\hline \multirow{2}{*}{$\begin{array}{c}\text { Days } \\
\text { post coitum }\end{array}$} & \multicolumn{2}{|c|}{ Progesterone (ng/ml) } & \multirow{2}{*}{$\begin{array}{c}\begin{array}{c}\text { Protein } \\
(\mathrm{mg} / \mathrm{ml})\end{array} \\
\text { Uterine flushings }\end{array}$} & \multirow{2}{*}{$\frac{\begin{array}{c}\text { Uteroglobin } \\
(\mathrm{mg} / \mathrm{ml})\end{array}}{\text { Uterine flushings }}$} \\
\hline & Plasma & Uterine flushings & & \\
\hline 0 & $<0 \cdot 2^{*}$ & $<0 \cdot 2^{*}$ & 0.12 & $\ldots *$ \\
\hline 1 & $<0.2^{*}$ & $<0.2^{*}$ & 0.20 & $\ldots *$ \\
\hline 2 & $2 \cdot 3,1 \cdot 3$ & $<0.2^{*}$ & 0.18 & $---^{*}$ \\
\hline 3 & $2 \cdot 8,2 \cdot 5$ & $<0 \cdot 2^{*}$ & $0 \cdot 20$ & 0.04 \\
\hline 4 & $5 \cdot 2,3 \cdot 6$ & $1 \cdot 1,0 \cdot 8$ & 0.50 & $0 \cdot 18$ \\
\hline 5 & $5 \cdot 4,3 \cdot 6$ & $2 \cdot 5,1 \cdot 4$ & 0.90 & 0.28 \\
\hline 6 & $6 \cdot 9,5 \cdot 3$ & $26 \cdot 0,18 \cdot 4$ & $I \cdot 14$ & 0.36 \\
\hline
\end{tabular}

* Below sensitivity of assay. 
Pregnancy was associated therefore with increased progesterone, total protein and uteroglobin concentrations in uterine flushings 4-6 days after mating, the progesterone increase being the most rapid. By using a molecular weight of 15,000 for uteroglobin (Murray, McGaughy \& Yarus, 1972), we calculate a ratio of one molecule of progesterone to $3000-4000$ molecules of uteroglobin on Days 4 and 5 post coitum. On Day 6 there is about one molecule of progesterone to 400 molecules of uteroglobin. The reason for this abrupt change is unknown, and the precise role that progesterone in the rabbit uterine secretions plays in implantation and early embryonic development needs to be investigated further.

These investigations were supported in part by Research Grants HD 05085 and HD 04274 of the NICHD, NIH, U.S. Department of Health, Education and Welfare.

\section{References}

Arthur, A.T. \& Daniel, J.C., Jr (1972) Progesterone regulation of blastokinin production and maintenance of rabbit blastocysts transferred into uteri of castrate recipients. Fert. Steril. 23, 115-122.

Arthur, A.T., Cowan, B.D. \& Daniel, J.C., JR (1972) Steroid binding to blastokinin. Fert. Steril. 23, 85-92.

BeAto, M. \& BaIER, R. (1975) Binding of progesterone to the proteins of the uterine luminal fluid. Biochim. biophys. Acta 392, 346-356.

BeIER, H.M. (1968a) Biochemisch-entwicklungphysiologische Untersuchungen des Kaninchens (Oryctolagus cuniculus). Zool. Jahrb. Anat. 85, 72-190.

BEIER, H.M. (1968b) Uteroglobin: a hormone-sensitive endometrial protein involved in blastocyst development. Biochim. biophys. Acta 160, 289-291.

Bullock, D.W. \& ConNell, K.M. (1973) Occurrence and molecular weight of rabbit uterine "blastokinin." Biol. Reprod. 9, 125-132.

CARr, B.R., Mikhail, G. \& Flickinger, G.L. (1971) Column chromatography of steroids on Sephadex LH-20. J. clin. Endocr. Metab. 33, 358-360.

Ekins, R. \& Newman, B. (1970) Theoretical aspects of saturation analysis. Acta endocr., Copenh., Suppl. 147, 11-30.

El Banna, A.A. \& Daniel, J.C., JR (1972a) Stimulation of rabbit blastocysts in vitro by progesterone and uterine proteins in combination. Fert. Steril. 23, 101-104.

Et. Banna, A.A. \& DANiel, J.C., JR (1972b) The effect of protein fractions from rabbit uterine fluids on embryo growth and uptake of nucleic acid and protein precursors. Fert. Steril. 23, 105-114.

Johansson, E.D.B. (1969) Progesterone levels in peripheral plasma during the luteal phase of the normal human menstrual cycle measured by a rapid competitive protein binding technique. Acta endocr., Copenh. 61, 592-606.
Johnson, M.A., Cowan, B.D. \& Daniel, J.C., JR (1972) An immunologic assay for blastokinin. Fert. Steril. 23, 93-100.

KRIShNaN, R.S. \& Daniel, J.C., JR (1967) "Blastokinin": inducer and regulator of blastocyst development in the rabbit uterus. Science, N.Y. 158, $490-492$.

Lowry, O.H., Rosebrough, N.J., FARR, A.L. \& RANDALL, R.J. (1951) Protein measurement with the Folin phenol reagent. J. biol. Chem. 193, 265-275.

MURPHY, B. (1971) Sephadex column chromatography as an adjunct to competitive protein binding assays of steroids. Nature, New Biol. 232, 21-24.

Murphy, B., Engelberg, W. \& Patlee, C.S. (1963) Simple method for the determination of plasma corticoids. J. clin. Endocr. Metab. 23, 293300 .

Murray, F.A., McGaughy, R.W. \& Yarus, M.J. (1972) Blastokinin: its size and shape, and an indication of the existence of subunits. Fert. Steril. 23, 69-77.

Neill, J.D., Johansson, E.D.B., Datta, S.K. \& KNoBIL, E. (1967) Relationship betweeen plasma levels of luteinizing hormone and progesterone during the normal menstrual cycle. J. clin. Endocr. Metab. 27, 1167-1173.

Seamark, R.F. \& Lutwak-Mann, C. (1972) Progesterone in rabbit blastocysts. J. Reprod. Fert. 29, 147-148.

ScHwick, H.G. (1965) Chemisch-entwicklungs-physiologische Beziehunge von Uterus zu Blastocyste des Kanichens (Oryctolagus cuniculus). Wilhelm Roux Arch. EntwMech. Org. 156, 283-343.

Urzua, M.A., Stambaugh, R., Flickinger, G. \& MastrolanNi, L. (1970) Uterine and oviduct fluid protein patterns in the rabbit before and after ovulation. Fert. Steril. 21, 860-866.

Received 20 December 1975 